\title{
PENGARUH KUALITAS PELAYANAN DIVISI SALES TERHADAP KEPUASAN PELANGGAN DI PT NIPRESS, Tbk
}

\author{
${ }^{1)}$ Muhlis, ${ }^{2)}$ Siska Mediterania \\ ${ }^{1)}$ Dosen Tetap Program Studi Manajemen, STIE Dewantara \\ J1. Raya Pemda Bojong Depok Baru III Karadenan Cibinong Bogor, Jawa Barat 16913, Indonesia \\ Email: muhlis@dewantara.ac.id \\ ${ }^{2)}$ Alumni Program Studi Manajemen, STIE Dewantara \\ J1. Raya Pemda Bojong Depok Baru III Karadenan Cibinong Bogor, Jawa Barat 16913, Indonesia \\ Email: siska.mediterania24@gmail.com
}

\begin{abstract}
This study aims to determine the quality of service sales division of customer satisfaction at PT. Nipress, Tbk. This study uses a questionnaire as an instrument to take a sample of 77 respondents, who are customers at PT. Nipess, Tbk. Data analysis uses multiple linear regression. The results of data analysis using multiple linear regression showed that the reliability variable partially had a significant effect on customer satisfaction at PT. Nipress, Tbk. Simultaneously tangibles,, reliability, responsiveness, assurance and empathy have a significant effect on customer satisfaction. The magnitude of the influence of tangibles, reliability, responsiveness, assurance and empathy variables is $47.3 \%$ while the rest is influenced by other variables not discussed in this study.
\end{abstract}

Keywords: Service Quality, Customer Satisfaction, PT Nipress, Tbk.

\section{ABSTRAK}

Penelitian ini bertujuan untuk mengetahui kualitas pelayanan divisi sales terhadap kepuasan pelanggan di PT. Nipress, Tbk. Penelitian ini menggunakan kuesioner sebagai instrument untuk mengambil sampel sebanyak 77 orang responden, yang merupakan pelanggan di PT. Nipess, Tbk. Analisis data menggunakan regresi linier berganda. Hasil analisis data dengan menggunakan regresi linier berganda menunjukkan bahwa secara parsial variabel kehandalan berpengaruh signifikan terhadap kepuasan pelanggan di PT. Nipress, Tbk. Secara simultan bukti fisik, kehandalan, daya tanggap, jaminan dan empati berpengaruh signifikan terhadap kepuasan pelanggan . Besarnya pengaruh variabel bukti fisik, kehandalan, daya tanggap, jaminan dan empati adalah sebesar $47,3 \%$ sedangkan sisanya dipengaruhi oleh variabel lain yang tidak dibahas dalam penelitian ini.

Kata kunci: Kualitas Pelayanan, Kepuasan Pelanggan, PT Nipress, Tbk.

\section{PENDAHULUAN}

\subsection{Latar Belakang}

Kepuasan pelanggan merupakan tingkat perasaan seseorang setelah membandingkan kinerja yang dirasakan dengan harapan. Dari pengertian di atas dapat dipahami bahwa peran kualitas pelayanan yang baik merupakan hal sangat penting dan berpengaruh, tanpa adanya pelayanan yang tepat produk akan kurang diminati oleh konsumen,

Dalam hal ini memiliki pelanggan dapat diartikan sejauh mana perusahaan mempertahankan pelanggan dimana hal ini berkaitan erat dengan kepuasan pelanggan, tingkat penjualan produk aki di PT. Nipress

Tbk bisa mempengaruhi kepuasan pelanggannya, adapun grafik penjualan pada tahun 2015-2018 sebagai berikut :

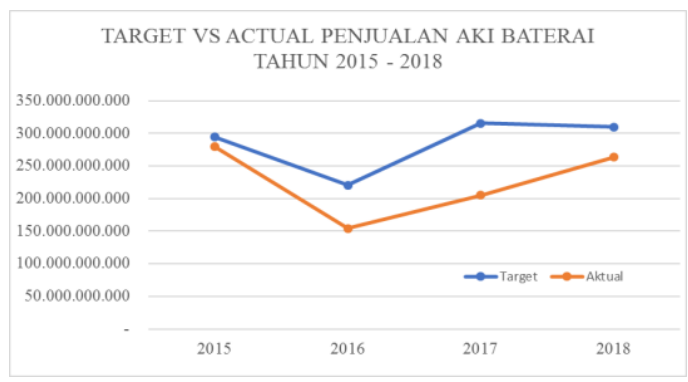

Gambar 1. Penjualan PT Nipress, Tbk 
Pada gambar di atas dapat dilihat target yang dimiliki PT Nipress, Tbk pada tahun 2016 mengalami penurunan karena persaingan antar perusahaan sejenis dengan teknologi terbaru bergaransi 10 (sepuluh) tahun membuat PT. Nipress, Tbk harus bersaing dengan ketat di dunia dan pasar lokal, kemudian target mulai kembali naik pada tahun 2017. Secara keseluruhan target yang ditetapkan PT Nipress, Tbk tidak tercapai dari tahun ke tahun akan tetapi angka penjualan mulai meningkat kembali pada tahun 2017. Oleh karena itu, PT. Nipress Tbk dituntut untuk selalu menjaga kepercayaan konsumen dengan meningkatkan kualitas pelayanan dan penyediaan fasilitas agar kepuasan konsumen meningkat.

\subsection{Ruang Lingkup Permasalahan}

Dalam skripsi ini difokuskan pada kualitas pelayanan divisi sales terhadap pelanggan, dimana bagian sales dapat mengetahui kepuasan pelanggannya agar bisa menjadi improvement kedepannya.

\subsection{Rumusan Masalah}

Berdasarkan di atas maka dapat dirumuskan masalah penelitian yaitu:

1. Apakah kualitas pelayanan divisi sales PT. Nipress, Tbk yang meliputi bukti fisik (tangibles) mempunyai pengaruh terhadap tingkat kepuasan pelanggan?

2. Apakah kualitas pelayanan divisi sales PT. Nipress, Tbk yang meliputi kehandalan (reliability) mempunyai pengaruh parsial terhadap tingkat kepuasan pelanggan?

3. Apakah kualitas pelayanan divisi sales PT. Nipress, Tbk yang meliputi daya tanggap (responsiveness) mempunyai pengaruh terhadap tingkat kepuasan pelanggan?

4. Apakah kualitas pelayanan divisi sales PT. Nipress, Tbk yang meliputi jaminan (assurance) mempunyai pengaruh terhadap tingkat kepuasan pelanggan?
5. Apakah kualitas pelayanan divisi sales PT. Nipress, Tbk yang meliputi empati (emphaty) mempunyai pengaruh terhadap tingkat kepuasan pelanggan?

6. Apakah kualitas pelayanan divisi sales PT. Nipress, Tbk yang meliputi bukti fisik, kehandalan, daya tanggap, jaminan, dan empati mempunyai pengaruh secara simultan terhadap tingkat kepuasan pelanggan?

7. Berapa besar pengaruh dari kualitas layanan divisi sales yang meliputi bukti fisik, kehandalan, daya tanggap, jaminan, dan empati terhadap tingkat kepuasan pelanggan di PT. Nipress, Tbk?

\subsection{Tujuan}

Berdasarkan rumusan masalah di atas, maka tujuan dari penelitian ini adalah:

1. Untuk mengetahui apakah kualitas pelayanan divisi sales PT. Nipress, Tbk yang meliputi bukti fisik mempunyai pengaruh terhadap tingkat kepuasan pelanggan.

2. Untuk mengetahui apakah kualitas pelayanan divisi sales PT. Nipress, Tbk yang meliputi kehandalan, mempunyai pengaruh terhadap tingkat kepuasan pelanggan.

3. Untuk mengetahui apakah kualitas pelayanan divisi sales PT. Nipress, Tbk yang meliputi daya tanggap mempunyai pengaruh terhadap tingkat kepuasan pelanggan.

4. Untuk mengetahui apakah kualitas pelayanan divisi sales PT. Nipress, Tbk yang meliputi jaminan mempunyai pengaruh terhadap tingkat kepuasan pelanggan.

5. Untuk mengetahui apakah kualitas pelayanan divisi sales PT. Nipress, Tbk yang meliputi empati mempunyai pengaruh terhadap tingkat kepuasan pelanggan.

6. Untuk mengetahui apakah kualitas pelayanan divisi sales PT. Nipress, 
Tbk yang meliputi bukti fisik, kehandalan, daya tanggap, jaminan, dan empati mempunyai pengaruh signifikan secara simultan terhadap tingkat kepuasan pelanggan.

7. Untuk mengetahui berapa besar pengaruh dari kualitas layanan divisi sales yang meliputi dari variabel bukti fisik, daya tanggap, kehandalan, jaminan, dan empati terhadap tingkat kepuasan pelanggan.

\section{TINJAUAN PUSTAKA}

\subsection{Pengertian Kualitas Pelayanan}

Menurut Tjiptono (2011) menyebutkan bahwa kualitas pelayanan jasa adalah tingkat keunggulan yang diharapkan dan pengendalian atas tingkat keunggulan tersebut untuk memenuhi keinginan pelanggan. Kualitas pelayanan dapat didefinisikan sebagai seberapa jauh perbedaan antara kenyataan dan harapan para pelanggan atas layanan yang mereka terima. Kualitas pelayanan dapat diketahui dengan cara membandingkan persepsi para pelanggan atas layanan yang mereka terima.

\subsection{Pengertian Kepuasan Pelanggan}

Kolter dalam Sunyoto (2013) kepuasan pelanggan merupakan tingkat perasaan seseorang setelah membandingkan kinerja yang dirasakan dengan harapan. Dari definisi di atas dapat ditarik kesimpulan bahwa pada dasarnya pengertian kepuasan pelanggan mencakup perbedaan antara harapan dan kinerja atau hasil yang dirasakan. Kepuasan pelanggan diperoleh jika kinerja suatu produk dapat memenuhi atau melebihi harapan pelanggan, dan konsumen akan merasa tidak puas jika kinerja suatu produk kurang dari yang diharapkan konsumen.

\subsection{Pengaruh Kualitas Pelayanan} terhadap Kepuasan Pelanggan

Dari pendapat yang dikemukakan Juran (1998) yang menyatakan bahwa kepuasan pelanggan dapat dilihat bila kualitas pelayanan yang telah diberikan dapat memenuhi keperluan pelanggan. Ada beberapa hal yang menunjukan pengaruh antara kualitas pelayanan dengan kepuasan pelanggan diantaranya sebagai berikut :

a. Kualitas pelayanan yang lebih baik memungkinkan perusahaan untuk meningkatkan kepuasan dan mengurangi ketidakpuasan pelanggan. Semakin baik kualitas pelayanan akan mengrangi kerja ulang pada akhirnya angka ketidakpuasan pelanggan dapat ditekan.

b. Bila kualitas pelayanan menunjukan kepuasan yang tinggi, maka akan terjadi penekanan biaya pada titik yang rendah dan akan menjadikan pelnaggan mengurangi biaya yang dikeluarkan faktor-faktor yang rendah menjadikan salah satu penentu kepuasan pelanggan.

\subsection{Kerangka Pemikiran}

Jika di lihat pembahasan dari teori di atas maka disimpulkan kerangka pemikiran sebagai berikut :

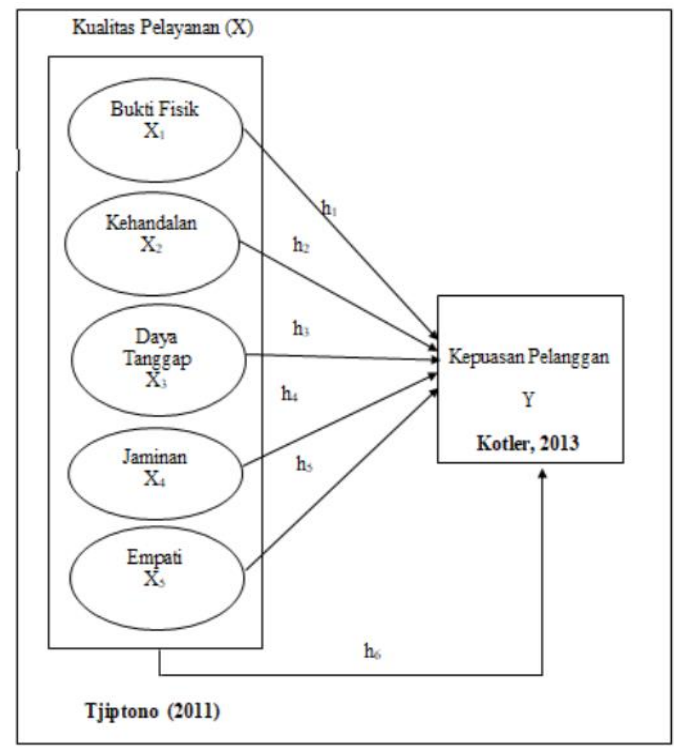

Gambar 2. Kerangka Pemikiran 


\section{METODE PENELITIAN}

\subsection{Jenis Penelitian}

Penelitian ini menggunakan jenis Kausalitas dimana penelitian ini dilakukan untuk mencari hubungan antara satu variabel dengan variabel yang lainnya.

\subsection{Variabel Penelitian}

Variabel dependen (terikat) adalah variabel yang nilainya tergantung dari nilai variabel lainnya (Y) dan variabel independen (bebas) adalah variabel yang nilainya tidak tergantung pada variabel lain (X).

1. Kepuasan pelanggan sebagai variabel dependen (terikat) atau variabel Y.

2. Kualitas pelanggan yang terdiri dari bukti fisik, kehandalan, daya tanggap, jaminan dan empati sebagai variabel independen (bebas) atau sebagai variabel $\mathrm{X}$.

\subsection{Lokasi dan Waktu Penelitian}

Penelitian ini dilakukan di PT Nipress, Tbk beralamat di Jl. Raya Narogong KM. 26 Cileungsi - Bogor. Waktu penelitian dimulai dari Februari 2019 sampai dengan Maret 2019.

\subsection{Populasi dan Sampel}

Populasi dalam penelitian ini adalah pelanggan PT Nipress, Tbk sebanyak 94 pelanggan, yang terdiri dari perusahaan BUMN dan perusahaan swasta.

Sampel dihitung berdasarkan rumus Slovin. Dalam penelitian ini tingkat derajat kepercayaan sebesar 95\%, maka tingkat kesalahan sebesar 5\%. Berdasarkan perhitungan tersebut maka jumlah sample yang akan dipilih daam penelitian ini adalah 77 responden.

\subsection{Teknik Pengumpulan Data}

Teknik pengumpulan data yang digunakan dalam penelitian ini adalah :

1. Teknik analisis data

a. uji validitas b. uji reliabilitas

2. Uji Asumsi Klasik

a. uji normalitas

b. uji multikolinearitas

c. uji heterokedastisitas

3. Analisis regresi linier berganda

4. Uji hipotesis
a. uji t
b. ujif

5. Koefisien determinasi

\section{HASIL DAN PEMBAHASAN}

\subsection{Teknik Analisis Data}

\subsubsection{Uji Validitas}

Uji validitas digunakan untuk mengukur sah atau valid tidaknya kuesioner. Suatu kuesioner dikatakan valid jika item-item pertanyaan mampu mengungkap suatu yang akan diukur oleh kuesioner tersebut.

Jika $\mathrm{r}_{\text {hitung }}>\mathrm{r}$ table, maka pernyataan dikatakan valid.

Jika $r$ hitung $\leq r$ table, maka pernyataan dikatakan tidak valid.

Tabel 1. Hasil Uji Validitas

\begin{tabular}{|c|c|c|c|c|}
\hline Variabel & Pernyataan & r-tabel & r-hitung & Kriteria \\
\hline \multirow{4}{*}{$\begin{array}{l}\text { Bukti Fisik } \\
\text { (Tangible) X1 }\end{array}$} & 1 & 0,224 & 0,748 & $\begin{array}{l}\text { Valid } \\
\end{array}$ \\
\hline & 2 & 0,224 & 0,844 & Valid \\
\hline & 3 & 0,224 & 0,805 & Valid \\
\hline & 4 & 0,224 & 0,854 & Valid \\
\hline \multirow{4}{*}{$\begin{array}{c}\text { Kehandalan } \\
\text { (Reliability) } \mathrm{X}_{2}\end{array}$} & 1 & 0,224 & 0,832 & Valid \\
\hline & 2 & 0,224 & 0,874 & Valid \\
\hline & 3 & 0,224 & 0,75 & Valid \\
\hline & 4 & 0,224 & 0,894 & Valid \\
\hline \multirow{4}{*}{$\begin{array}{c}\text { Daya Tanggap } \\
\text { (Responsiveness } \\
\text { ) } \mathrm{X}_{3}\end{array}$} & 1 & 0,224 & 0,828 & Valid \\
\hline & 2 & 0,224 & 0,712 & Valid \\
\hline & 3 & 0,224 & 0,798 & Valid \\
\hline & 4 & 0,224 & 0,836 & Valid \\
\hline \multirow{4}{*}{$\underset{\text { (Assurance) }}{\text { Jaminan }} \mathrm{X}_{4}$} & 1 & 0,224 & 0,861 & Valid \\
\hline & 2 & 0,224 & 0,72 & Valid \\
\hline & 3 & 0,224 & 0,826 & Valid \\
\hline & 4 & 0,224 & 0,755 & Valid \\
\hline \multirow{4}{*}{$\underset{\text { (emphaty) } \mathrm{X}_{5}}{\text { Empati }}$} & 1 & 0,224 & 0,97 & Valid \\
\hline & 2 & 0,224 & 0,899 & Valid \\
\hline & 3 & 0,224 & 0,967 & Valid \\
\hline & 4 & 0,224 & 0,963 & Valid \\
\hline $\begin{array}{c}\text { Kepuasan } \\
\text { Pelanggan } 1\end{array}$ & 1 & 0,224 & 0,926 & Valid \\
\hline $\begin{array}{c}\text { Kepuasan } \\
\text { Pelanggan } 2\end{array}$ & 2 & 0,224 & 0,821 & Valid \\
\hline $\begin{array}{c}\text { Kepuasan } \\
\text { Pelanggan } 3\end{array}$ & 3 & 0,224 & 0,666 & Valid \\
\hline $\begin{array}{c}\text { Kepuasan } \\
\text { Pelanggan } 4\end{array}$ & 4 & 0,224 & 0,747 & Valid \\
\hline $\begin{array}{c}\text { Kepuasan } \\
\text { Pelanggan } 5\end{array}$ & 5 & 0,224 & 0,907 & Valid \\
\hline
\end{tabular}

Sumber: Olah data 2019 
Berdasarkan pengujian pada tabel di atas dapat diketahui bahwa nilai rhitung dari semua indikator lebih besar dari nilai $r$ tabel nya. Probabilitas kesalahan (sig) dari tiap-tiap indikator semuanya dibawah 0,05 oleh karena itu dapat disimpulkan bahwa semua pertanyaan pada kuesioner dalam penelitian ini adalah valid.

\subsubsection{Uji Reliabilitas}

Uji reliabilitas menunjukan ada suatu pengertian bahwa sesuatu instrument cukup dipercaya untuk baik digunakan sebagai alat pengumpulan data karena instrument tersebut sudah baik.

Suatu angket dikatakan reliabel jika jawaban seseorang terhadap pertanyaan konsisten dari waktu ke waktu. Pengujian reabilitas data dilakukan dengan membandingkan koefisien Alpha (cronbach's alpha). Suatu kuesioner dikatakan reliable jika alpha $>0,6$ dan Jika Alpha < 0,6 maka dapat dikatakan tidak reliabel

Tabel 2. Hasil Uji Reliabilitas

\begin{tabular}{|c|c|c|c|}
\hline Variabel & Nilai Ketentuan & $\begin{array}{c}\text { Nilai Cronbachs } \\
\text { Alpha }\end{array}$ & Kriteria \\
\hline Bukti Fisik $\left(\mathrm{X}_{1}\right)$ & $>0,60$ & 0,825 & Reliable \\
\hline Kehandalan $\left(\mathrm{X}_{2}\right)$ & $>0,60$ & 0,712 & Reliable \\
\hline $\begin{array}{c}\text { Daya Tanggap } \\
\left(\mathrm{X}_{3}\right)\end{array}$ & $>0,60$ & 0,847 & Reliable \\
\hline Jaminan $\left(\mathrm{X}_{4}\right)$ & $>0,60$ & 0,789 & Reliable \\
\hline Empati $\left(\mathrm{X}_{3}\right)$ & $>0,60$ & 0,963 & Reliable \\
\hline $\begin{array}{c}\text { Kualitas } \\
\text { Pelayanan }(\mathrm{Y})\end{array}$ & $>0,60$ & 0,876 & Reliable \\
\hline
\end{tabular}

Sumber: Olah data 2019

Berdasarkan table di atas diperoleh hasil bahwa variabel bukti fisik, kehandalan, daya tanggap, jaminan, empati dan keputusan pelanggan adalah reliabel yaitu dimana nilai Alpha Cronbach masing-masing variabel lebih besar dari 0,60 .

\subsection{Uji Asumsi Klasik}

\subsubsection{Uji Normalitas}

Uji normalitas adalah pengujian apakah dalam model regresi, variabel bebas dan variabel terikatnya terdistribusi normal atau tidak. Pada penelitian ini cara yang dilakukan untuk melihat normalitas, yaitu analisis grafik, analisis ini dilakukan dengan melihat tampilan grafik histogramnya, tetapi akan lebih kuat jika melihat pada normal probability plot / grafik normal plotnya.

\section{Tabel 3. Hasil Uji Normalitas}

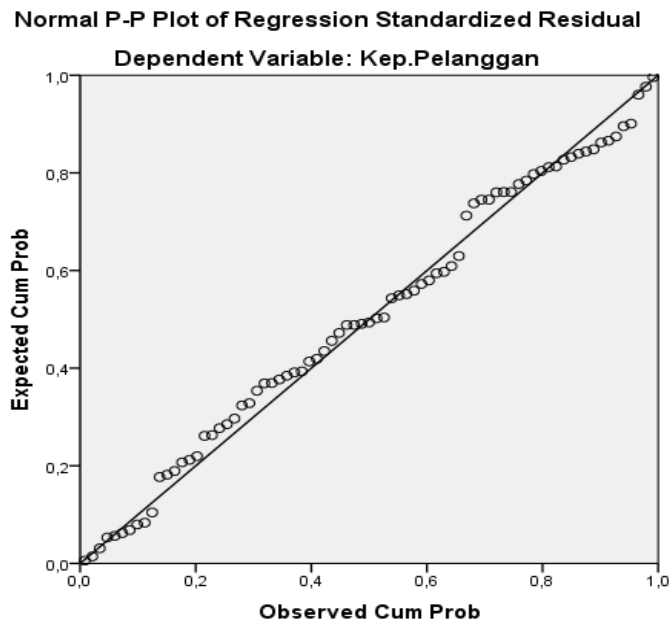

\section{Gambar 3. P-Plot of Regression Standarized Residual}

Berdasarkan tampilan output di atas dapat dilihat grafik P-Plot tersebut terlihat titik-titik mengikuti dan mendekati garis diagonalnya sehingga dapat disimpulkan bahwa data berdistribusi normal.

\subsubsection{Uji Multikolinearitas}

Multikolonieritas didteksi dengan menggunakan nilai tolerance dan variance inflation factor (VIF). Tolerance mengukur variabilitas variabel bebas yang terpilih yang tidak dapat dijelaskan oleh variabel bebas lainnya. Jadi nilai tolerance yang rendah sama dengan nilai VIF yang tinggi (arena $\mathrm{VIF}=1 /$ tolerance) dan menunjukkan adanya kolinearitas yang tinggi. Nilai yang 
umum dipakai adalah nilai tolerance 0,05 atau sama dengan nilai VIF dibawah 10.

Tabel 4. Hasil Uji Multikolinearitas

\begin{tabular}{|l|c|c|}
\hline \multicolumn{1}{|c|}{ Variabel } & VIF & Keterangan \\
\hline Bukti Fisik & 1,054 & $\begin{array}{c}\text { tidak terjadi gejala } \\
\text { multikolinearitas }\end{array}$ \\
\hline Kehandalan & 1,175 & $\begin{array}{c}\text { tidak terjadi gejala } \\
\text { multikolinearitas }\end{array}$ \\
\hline $\begin{array}{l}\text { Daya } \\
\text { Tanggap }\end{array}$ & 1,012 & $\begin{array}{c}\text { tidak terjadi gejala } \\
\text { multikolinearitas }\end{array}$ \\
\hline Jaminan & 1,026 & $\begin{array}{c}\text { tidak terjadi gejala } \\
\text { multikolinearitas }\end{array}$ \\
\hline Empati & 1,123 & $\begin{array}{c}\text { sidak terjadi gejala } \\
\text { multikolineritas }\end{array}$ \\
\hline
\end{tabular}

Sumber: Olah data 2019

Hasil pengujian menunjukkan bahwa nilai VIF dari semua variabel memiliki nilai yang lebih kecil dari 10. Hal ini berarti bahwa variable-variabel dalam penelitian tidak menunjukkan adanya gejala multikolonieritas dalam model regresi.

\subsubsection{Uji Heterokedastisitas}

Uji heterokedastisitas dilakukan untuk mengetahui apakah dalam sebuah model regresi terjadi ketidaksamaan varians dari residual suatu pengamatan ke pengamatan lain.

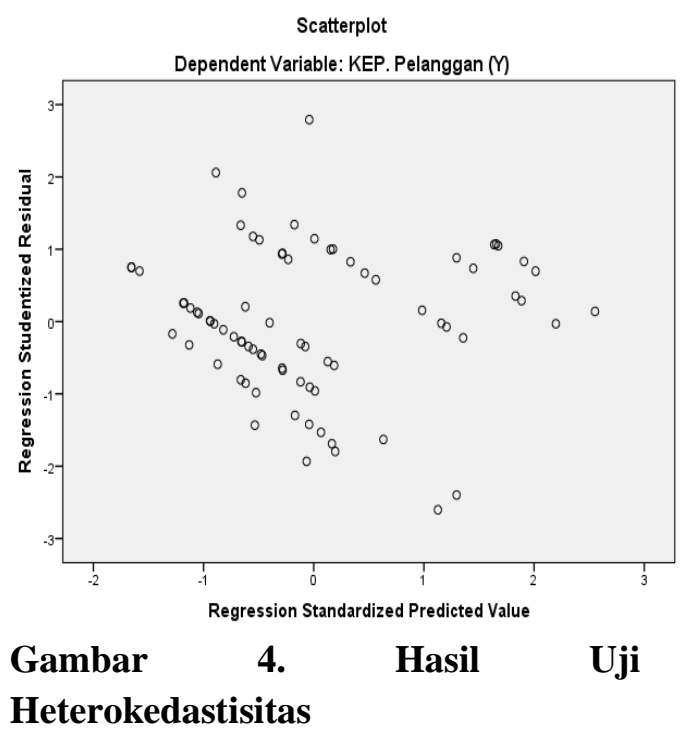

Dapat disimpulkan bahwa hasil pengolahan data heteroskedastisitas diperoleh titik - titik data menyebar secara acak dan tersebar baik di atas maupun dibawah angka 0 dan sumbu $Y$, titik - titik data tidak membentuk pola bergelombang melebar kemudian menyempit dan melebar kembali, penyebaran titik - titik dan tidak berpola. Hal ini dapat disimpulkan bahwa tidak terjadi heteroskedastisitas pada model regresi, sehingga model regresi layak untuk digunakan dalam melakukan pengujian.

\subsection{Analisis Regresi Linier Berganda}

Analisis regresi berganda digunakan untuk meramaikan bagaimana keadaan naik turunnya variabel dependen, bila dua atau lebih variabel independen sebagai indikator.analsiis ini digunakan untuk melibatkan dua atau lebih variabel bebas antara variabel dependen Kepuasan Pelanggan (Y), variabel independen Bukti Fisik (Tangible), Kehandalan (Reliability), Daya tanggap (Responsiveness), Jaminan (Assurance),, Empati (Emphaty).

\section{Tabel 5. Hasil Uji Regresi Linier Berganda}

Coefficients $^{\mathrm{a}}$

\begin{tabular}{|c|c|c|c|c|c|c|}
\hline \multirow[b]{2}{*}{ Model } & & \multicolumn{2}{|c|}{ Unstandardized Coefficients } & \multirow{2}{*}{$\begin{array}{c}\begin{array}{c}\text { Standardized } \\
\text { Coefficients }\end{array} \\
\text { Beta }\end{array}$} & \multirow[b]{2}{*}{$t$} & \multirow[b]{2}{*}{ Sig. } \\
\hline & & $B$ & Std. Eiror & & & \\
\hline 1 & (Constant) & 3,976 & 4,109 & & 967 &, 337 \\
\hline & Bukti Fisik (X1) &,- 065 &, 073 & -077 & ; 895 & 374 \\
\hline & Kehandalan (X2) & 986 &, 139 &, 640 & 7,095 &, 000 \\
\hline & Daya Tanggap (X3) &, 170 &, 102 &, 139 & 1,660 &, 101 \\
\hline & Jaminan (X4) & -011 &, 104 & ;,009 & -107 &, 915 \\
\hline & Empati (X5) & -079 &, 082 & -085 & .965 &, 338 \\
\hline
\end{tabular}

a. Dependent Variable: KEP. Pelanggan (Y)

Sumber: Olah data 2019

Berdasarkan hasil regresi di atas maka diperoleh persamaan garis regresi linier sebagai berikut:

$\mathrm{Y}=3,976-0,065 \mathrm{X}_{1}+0,986 \mathrm{X}_{2}+0,170 \mathrm{X}_{3}-$ $0,011 \mathrm{X}_{4}-0,079 \mathrm{X}_{5}+\mathrm{e}$

Dari hasil persamaan regresi linier berganda di atas maka dapat dijelaskan sebagai berikut: 
a. Nilai $-0,065$ mempunyai arti bahwa jika terjadi kenaikan satuan nilai variabel bukti fisik, maka akan mengurangi nilai kepuasan pelanggan sebesar 0,065 .

b. Nilai 0,986 mempunyai arti bahwa jika terjadi kenaikan satuan nilai variabel kehandalan, maka akan menambah nilai kepuasan pelanggan sebesar 0,986 .

c. Nilai 0,170 mempunyai arti bahwa jika terjadi kenaikan satuan nilai variabel daya tanggap, maka akan menambah nilai kepuasan pelanggan sebesar 0,170 .

d. Nilai -0,011 mempunyai arti bahwa jika terjadi kenaikan satuan nilai variabel jaminan, maka akan mengurangi nilai kepuasan pelanggan sebesar 0,011 .

e. Nilai -0,079 mempunyai arti bahwa jika terjadi kenaikan satuan nilai variabel empati, maka akan mengurangi nilai kepuasan pelanggan sebesar 0,079 .

f. Nilai konstanta 3,976 ini mempunyai arti bahwa jika varibel bebas memiliki nilai nol maka pelayanan maka nilai kepuasan pelanggan sebesar 13,976.

\subsection{Uji Hipotesis}

\subsubsection{Uji t (Uji Parsial)}

Uji t digunakan untuk mengetahui apakah variabel $\mathrm{X}$ secara parsial (sendiri) berpengaruh signifikan terhadap variabel $\mathrm{Y}$.

a. Jika nilai $t_{\text {hitung }}>t_{\text {tabel }}$ maka variabel $X$ berpengaruh terhadap variabel $Y$.

b. Jika nilai $t_{\text {hitung }} \leq t_{\text {tabel }}$ maka variabel $X$ tidak berpengaruh terhadap variabel Y.

Berdarkan nilai signifikansi

a. Jika nilai sig > 0,05 maka variabel $\mathrm{X}$ tidak berpengaruh signifikan terhadap variabel Y

b. Jika nilai sig $\leq 0,05$ maka variabel $\mathrm{X}$ berpengaruh signifikan terhadap variabel Y
Tabel 6. Hasil Uji t (Uji Parsial)

\begin{tabular}{|c|c|c|c|c|c|c|c|c|}
\hline \multicolumn{9}{|c|}{ Coefficients $^{\mathrm{a}}$} \\
\hline & & \multicolumn{2}{|c|}{ Unstandardized Coesficientis } & \multirow{2}{*}{$\begin{array}{c}\text { Standardized } \\
\text { Coefficients } \\
\text { Beta }\end{array}$} & \multirow[b]{2}{*}{ ! } & \multirow[b]{2}{*}{ Sig. } & \multicolumn{2}{|c|}{ Collineritity Stailisics } \\
\hline \multicolumn{2}{|c|}{ Model } & B & stal. Error & & & & Tolerance & $\mathrm{VIF}$ \\
\hline 1 & (Constant) & 3,976 & 4,109 & & 967 & .337 & & \\
\hline & Bultit Fisik(X1) & .065 & 073 & 年7 & ;895 & 374 & 949 & 1,054 \\
\hline & Kehandalan $\left(X_{2}\right)$ & 986 & 139 & 640 & 7,095 &, 000 & 851 & 1,175 \\
\hline & Dawa Tanggap (X3) & 170 & 102 &, 139 & 1,660 &, 101 & 988 & 1,012 \\
\hline & Jaminan (X4) & -011 & 104 & ; 009 & 107 & 915 & 975 & 1,026 \\
\hline & Empati $\left(X_{5}\right)$ & -079 & 082 & -085 & -995 & 338 & 891 & 1,123 \\
\hline
\end{tabular}

Sumber: Olah data 2019

Berdasarkan pada uji t di atas, untuk mengetahui besarnya pengaruh masingmasing variabel independen secara parsial terhadap variabel dependen adalah sebagai berikut:

1. Variabel bukti fisik

Hasil pengujian diperoleh nilai output di atas (sig 0,374 > 0,05). Nilai signifikansi di atas 0,05 bukti fisik tidak memiliki pengaruh terhadap kepuasan pelanggan.

2. Variabel kehandalan

Hasil pengujian diperoleh nilai output di atas (sig $0,000<0,05$ ). Nilai signifikansi dibawah 0,05 kehandalan memiliki pengaruh terhadap kepuasan pelanggan.

3. Variabel daya tanggap

Hasil pengujian diperoleh nilai output di atas (sig 0,101 > 0,05). Nilai signifikansi di atas 0,05 daya tanggap tidak memiliki pengaruh terhadap kepuasan pelanggan.

4. Variabel jaminan

Hasil pengujian diperoleh nilai output di atas (sig 0,915>0,05). Nilai signifikansi di atas 0,05 jaminan tidak memiliki pengaruh kepuasan pelanggan.

5. Variabel empati

Hasil pengujian diperoleh nilai output di atas (sig 0,338>0,05). Nilai signifikansi di atas 0,05 empati tidak memiliki pengaruh terhadap kepuasan pelanggan. 


\subsubsection{Uji F (Uji Silmutan)}

Pengujian ini bertujuan untuk membuktikan apakah variabel bebas secara simultan bersama-sama mempunyai pengaruh terhadap variabel terikat.

Adapun kriteria pengujian uji $\mathrm{F}$ adalah sebagai berikut :

a. Dengan membandingkan nilai $\mathrm{f}_{\text {hitung }}$ dengan $\mathrm{f}_{\text {tabel }}$ :
a. Apabila $\mathrm{f}_{\text {tabel }}<\mathrm{f}_{\text {hitung }}$, maka Ho ditolak.
b. Apabila $f_{\text {tabel }} \geq f_{\text {hitung }}$, maka Ho diterima.

b. Dengan menggunakan angka probabilitas signifikansi :
a. Apabila probabilitas signifikansi > 0,05, maka Ho diterima.
b. Apabila probabilitas signifikansi $\leq$ 0,05 , maka Ho ditolak.

c. Kesimpulan keputusan

Apabila $\mathrm{f}_{\text {tabel }}<\mathrm{f}_{\text {hitung }}$, maka Ho ditolak dan $\mathrm{Ha}$ diterima, artinya variabel independen secara simultan mempengaruhi variabel dependen.

Apabila $f_{\text {tabel }} \geq f_{\text {hitung }}$, maka Ho diterima dan $\mathrm{Ha}$ ditolak, artinya variabel independen secara simultan tidak mempengaruhi variabel dependen.

Tabel 7. Hasil Uji F (Uji Simultan)

\begin{tabular}{|c|c|c|c|c|c|c|}
\hline \multicolumn{7}{|c|}{$A N O V A^{a}$} \\
\hline \multicolumn{2}{|c|}{ Model } & $\begin{array}{l}\text { Sum of } \\
\text { Squares }\end{array}$ & $d f$ & Mean Square & $F$ & Sig. \\
\hline \multirow[t]{3}{*}{1} & Regression & 284,447 & 5 & \multirow{3}{*}{$\begin{array}{r}56,889 \\
3,882\end{array}$} & \multirow[t]{3}{*}{14,654} & \multirow[t]{3}{*}{, 000} \\
\hline & Residual & 275,631 & 71 & & & \\
\hline & Total & 560,078 & 76 & & & \\
\hline & ntVarial & Pelangga & & & & \\
\hline & $\begin{array}{l}\text { tors: (Const } \\
\text { dalan X2) }\end{array}$ & & & & & \\
\hline
\end{tabular}

Sumber: Olah data 2019

Hasil perhitungan analisis menunjukkan nilai $f_{\text {hitung }}$ sebesar 14,654 dengan tingkat probabilitas 0,000 (signifikan). Sedangkan $\mathrm{f}_{\text {tabel }}$ sebesar 2,34 dengan demikian maka $f_{\text {hitung }}$ lebih besar dari $\mathrm{f}_{\text {tabel }}(14,654>2,34)$ yang artiya $\mathrm{H}_{0}$ ditolak dan $\mathrm{H}_{6}$ diterima dan juga probabilitas jauh lebih kecil dari 0,05, maka hipottsis uji f secara bersama-sama kualitas pelayanan divisi sales memiliki pengaruh positif dan dapat diterima, artinya memiliki pengaruh signifikan terhadap kepuasan pelanggan.

\subsection{Koefisien Determinasi}

Koefisien determinasi $\left(\mathrm{R}^{2}\right)$ pada intinya mengukur seberapa jauh kemampuan dalam model menerangkan perubahan variasi variabel bebas terhadap peubahan variasi variabel terikat. Nilai efesiensi determinasi adalah antara nol dan satu. Nilai $\mathrm{R}^{2}$ yang kecil berarti kemampuan variasi variable-variabel bebas dalam menjelaskan variasi variabel dependen sangat kecil.

\section{Tabel 8. Hasil Uji Koefisien Determinasi}

Model Summary
\begin{tabular}{|l|c|c|c|c|}
\hline Model & $R$ & R Square & $\begin{array}{c}\text { Adjusted R } \\
\text { Square }\end{array}$ & $\begin{array}{c}\text { Std. Error of } \\
\text { the Estimate }\end{array}$ \\
\hline 1 &, $713^{\text {a }}$ &, 508 &, 473 & 1,970 \\
\hline
\end{tabular}
a. Predictors: (Constant), Empati (X5), Jaminan (X4), Daya
Tanggap (X3), Bukti Fisik (X1), Kehandalan (X2)
b. Dependent Variable: KEP. Pelanggan ( $($ )

Sumber: Olah data 2019

Hasil perhitungan dapat diketahui bahwa koefisiensi determinasi (adjusted $R$ square) yang diperoleh sebesar 0,473 . Hal ini berarti $47,3 \%$ kepuasan pelanggan dipengaruhi oleh bukti fisik, daya tanggap, kehandalan, jaminan, empati. Sedangkan sisanya yaitu $52,7 \%$ kepuasan pelanggan dipengaruhi oleh variabel - variabel lainnya yang tidak diteliti dalam penelitian ini. Artinya untuk penelitian selanjutnya diharapkan dapat mencari variabel lain untuk melengkapi kekurangan 52,7\% yang mempengaruhi kepuasan pelanggan, misalnya dengan meneliti variabel bauran pemasaran terhadap kepuasan pelanggan di PT Nipress, Tbk. 


\section{KESIMPULAN DAN SARAN}

\subsection{Kesimpulan}

Hasil kesimpulan pada penelitian ini sebagai berikut :

1. Hasil pengujian pada analisis uji $t$ bahwa kualitas pelayanan yang terdiri dari bukti fisik tidak memiliki pengaruh terhadap kepuasan pelanggan.

2. Hasil pengujian pada analisis uji $t$ bahwa kualitas pelayanan yang terdiri dari kehandalan memiliki pengaruh terhadap kepuasan pelanggan.

3. Hasil pengujian pada analisis uji $t$ bahwa kualitas pelayanan yang terdiri dari daya tanggap tidak memiliki pengaruh terhadap kepuasan pelanggan.

4. Hasil pengujian pada analisis uji $t$ bahwa kualitas pelayanan yang terdiri dari jaminan tidak memiliki pengaruh terhadap kepuasan pelanggan.

5. Hasil pengujian pada analisis uji $t$ bahwa kualitas pelayanan yang terdiri dari empati tidak memiliki pengaruh terhadap kepuasan pelanggan.

6. Hasil pengujian uji $f$ menyatakan bahwa secara simultan keseluruhan variabel kualitas pelayanan berpengaruh terhadap kepuasan pelanggan.

7. Hasil uji koefisien determinasi (Adjusted R Square) sebesar 0,473.

\subsection{Saran}

\section{Bagi PT. Nipress, Tbk}

Berdasarkan hasil dari penelitian yang dilakukan menghasilkan bahwa variabel kehandalan yang memberikan pengaruh tehadap kepuasan pelanggan PT. Nipress, tbk sehingga perusahaan harus meningkatkan kehadalan tenaga penjualannya. Peningkatan kehandalan tenaga penjualan dapat dilakukan oleh perusahaan dengan cara memberikan pelatihan-pelatihan kepada tenaga penjualan sehingga dapat meningkatkan kehandalan tenaga penjualan.

\section{Bagi Peneliti Selanjutnya}

Penelitian selanjutkan dalam penelitian pengingkatan pelayaan di PT Nipress, tbk dapat dilakukan dengan sudut pandang metode lain atau dengan penggunakan varibel yang berbeda dengan penelitian ini. Selain itu untuk lebih dalam menindaklanjuti penelitian ini dapat diteliti lebih dalam mengenai variabel kehandalan.

\section{DAFTAR PUSTAKA}

Abdul Hakim. 2010. Statistika Deskriptif. Edisi Pertama. Kampus Fakultas Ekonomi UI, Yogyakarta

Budi Haryono. 2016. How To Win Customer Through Customer Service With Heart. CV. Andi Offset, Yogyakarta

Danang Sunyoto, dan Fathonah Eka Susanti. 2015. Manajemen Pemasaran Jasa. Edisi pertama. PT. Buku Seru, Yogyakarta.

Fandy Tjiptono dan Gregorius Chandra. 2016. Service, Quality dan Satisfaction. Edisi keempat. CV Andi Offset, Yogyakarta 1997. Strategi Pemasaran (Edisi II). Yogyakarta: Penerbit Andi.

Rizal Badudu. 2015. Service Excellence. PT. Kompas Media Nusantara, Jakarta.

Rangkuti, F. 1997, Riset Pemasaran. PT. Gramedia Pustaka Utama, Jakarta.

Ratminto dan Atik Septi Winarsih. 2005. Manajemen Pelayanan. Yogyakarta : Penerbit Pustakawan Belajar.

Ron Kaufman. 2012. Uplifting Service. PT. Zaytuna Ufuk Abadi, Jakarta.

Sugiyono, 2004. Metode Penelitian Bisnis. Bandung : Alfabeta.

Suharyadi dan Purwanto, 2004. Statistika untuk Ekonomi \& Keuangan Modern. Jakarta : PT. Salemba Empat. 
Economicus, Vol. 14 No. 1 - Juni 2020

Tatay Sutari. 2016. Service Is Nothing. PT.

Alex Media Komputindo, Jakarta.

Thamir Abdullah dan Francis Tantri.

Manajemen Pemasaran. 2012. PT.

Raja Grafindo Persada, Depok.

Ujang Sumarwan. 2015. Perilaku

Konsumen. Ghalia Indonesia, Bogor. 